\title{
The botanical origin and antioxidant, anti- BACE1 and antiproliferative properties of bee pollen from different regions of South Korea
}

Yuchi Zou ${ }^{1 \dagger}$, Jian $\mathrm{Hu}^{2+}$, Wenting Huang ${ }^{3}$, Liyun Zhu ${ }^{2}$, Mingjie Shao ${ }^{3}$, Confidence Dordoe ${ }^{2}$, Young-Joon Ahn ${ }^{4}$, Dongxue Wang ${ }^{2}$, Yeli Zhao ${ }^{2}$, Ye Xiong ${ }^{1 *}$ and Xue Wang ${ }^{1,2^{*}}$ (D)

\begin{abstract}
Background: Bee pollen (BP) has been used as a traditional medicine and food diet additive due to its nutritional and biological properties. The potential biological properties of bee pollen vary greatly with the botanical and geographical origin of the pollen grains. This study was conducted to characterize the botanical origin and assess the antioxidant effects of ethanol extracts of 18 different bee pollen (EBP) samples from 16 locations in South Korea and their inhibitory activities on human $\beta$-amyloid precursor cleavage enzyme (BACE1), acetylcholinesterase (AChE), human intestinal bacteria, and 5 cancer cell lines.

Methods: The botanical origin and classification of each BP sample was evaluated using palynological analysis by observing microscope slides. We measured the biological properties, including antioxidant capacity, inhibitory activities against human BACE1, and AChE, and antiproliferative activities toward five cancer cell lines, of the 18 EBPs. In addition, the growth inhibitory activities on four harmful intestinal bacteria, six lactic acid-producing bacteria, two nonpathogenic bacteria, and an acidulating bacterium were also assessed.

Results: Four samples (BP3, BP4, BP13 and BP15) were found to be monofloral and presented four dominant pollen types: Quercus palustris, Actinidia arguta, Robinia pseudoacacia, and Amygdalus persica. One sample (BP12) was found to be bifloral, and the remaining samples were considered to be heterofloral. Sixteen samples showed potent antioxidant activities with $\mathrm{EC}_{50}$ from 292.0 to $673.9 \mu \mathrm{g} \mathrm{mL}^{-1}$. Fourteen samples presented potent inhibitory activity against human BACE1 with $\mathrm{EC}_{50}$ from 236.0 to $881.1 \mathrm{\mu g} \mathrm{mL}^{-1}$. All samples showed antiproliferative activity toward the cancer cell lines PC-3, MCF-7, A549, NCl-H727 and AGS with IC 50 from 2.7 to $14.4 \mathrm{mg} \mathrm{mL}^{-1}, 0.9$ to $12.7 \mathrm{mg} \mathrm{mL}^{-1}$, 5.0 to $>25 \mathrm{mg} \mathrm{mL}^{-1}, 2.7$ to $17.7 \mathrm{mg} \mathrm{mL}^{-1}$, and 2.4 to $8.7 \mathrm{mg} \mathrm{mL}^{-1}$, respectively. In addition, total phenol and flavonoid contents had no direct correlation with antioxidant, anti-human BACE1, or antiproliferative activities.

(Continued on next page)
\end{abstract}

\footnotetext{
*Correspondence: xiongye2310@163.com; xinyuw001@163.com

${ }^{+}$Yu Chi Zou and Jian Hu contributed equally to this work.

'The First Affiliated Hospital of Wenzhou Medical University, Wenzhou, Zhejiang 325000, China

Full list of author information is available at the end of the article
}

(C) The Author(s). 2020 Open Access This article is licensed under a Creative Commons Attribution 4.0 International License, which permits use, sharing, adaptation, distribution and reproduction in any medium or format, as long as you give appropriate credit to the original author(s) and the source, provide a link to the Creative Commons licence, and indicate if changes were made. The images or other third party material in this article are included in the article's Creative Commons. licence, unless indicated otherwise in a credit line to the material. If material is not included in the article's Creative Commons licence and your intended use is not permitted by statutory regulation or exceeds the permitted use, you will need to obtain permission directly from the copyright holder. To view a copy of this licence, visit http://creativecommons.org/licenses/by/4.0/ The Creative Commons Public Domain Dedication waiver (http://creativecommons.org/publicdomain/zero/1.0/) applies to the data made available in this article, unless otherwise stated in a credit line to the data. 
(Continued from previous page)

Conclusion: Fundamentally, Korean bee pollen-derived preparations could be considered a nutritional addition to food to prevent various diseases related to free radicals, neurodegenerative problems, and cancers. The botanical and geographical origins of pollen grains could help to establish quality control standards for bee pollen consumption and industrial production.

Keywords: Bee pollen, Botanical origin, Antioxidant, Anti-BACE1, Antiproliferative, Biological properties

\section{Background}

There are many products, such as propolis, royal jelly, beeswax and bee pollen (BP), that are harvested from honey bees (Apis mellifera L.) [1]. Bee pollen is collected by worker honey bees from the pollen grains of flower anthers in plants and mixed with a secretion from their salivary glands or nectar. Pollen pellets are colorful and range from light yellow to black [2]. Pollen grains have diverse morphological characteristics, such as cylindrical, round, triangular, bell-shaped or thorny characteristics [3]. The composition of bee pollen is closely related to the plant source and geographical location, as well as other related factors, such as soil type, beekeeper activities, and climatic conditions [1]. The main components of bee pollen are reducing sugars (40.7\%, including 3.7\% sucrose), protein (32.8\%, including $11.5 \%$ essential amino acids), lipids (12.8\%), bioelements (4.0\%), vitamin C $(0.19 \%)$, and $\beta$-carotene $(0.07 \%)$ [2]. There is a wide assortment of commercial bee pollen products, so determining the quality of bee pollen in commercial products is required. However, only a few countries have officially standardized quality standards and limits of bee pollen and have permitted pollen use as a food additive; these countries include Argentina, Switzerland, Bulgaria, Poland, and Brazil $[4,5]$. In ancient times, pollen has been applied as a food supplement or food diet additive and has been used for centuries as a kind of traditional medicine due to its nutritional and biological properties [6, 7]. The therapeutic and biological properties of bee pollen include antioxidant [8-12], antiinflammatory [9], antimicrobial activities [10,11] and antitumor [13, 14] activities; improvement of semen quality and fertility [15]; hypolipidemic and hepatoprotective activity [2]; and anti-atherogenic activity [16]. These potential activities of pollen vary with botanical and geographical origin $[17,18]$. Assessment of the variety of beneficial biological properties and evaluation of the quality of bee pollen products has been a concern.

A previous study compared the sugar composition of bee pollen from China, South Korea, and Poland [19]. However, few studies have presented the biological activities of native South Korean bee pollen. In the current study, palynological identification of 18 bee pollen (BP) samples from A. mellifera collected from 16 different locations in South Korea was first analyzed. We also evaluated the biological features, including the antioxidant capacity based on 2,2-diphenyl-1-picrylhydrazyl (DPPH) free radical scavenging activity, inhibitory activities against human $\beta$-amyloid precursor cleavage enzyme (BACE1), human acetylcholinesterase (AChE), and antiproliferative activities toward five cancer cell lines (PC-3, MCF-7, A549, NCI-H727, and AGS), of bee pollen ethanol extracts (EBPs) for the first time. In addition, the growth inhibitory activities on four harmful intestinal bacteria, six lactic acid-producing bacteria, two nonpathogenic bacteria, and an acidulating bacterium were also assessed. In addition, the relationships between the total flavonoid and polyphenol contents and the biological properties of the 18 different EBP samples were also determined. The present study could provide insight into the influence of floral and geographical origin on the biological activities of bee pollen, which would contribute to the choice or establishment of a widely recognized quality standard for pollen products.

\section{Methods \\ Reagents}

Glycerol, quercetin, gallic acid, Folin-Ciocalteu's phenol reagent, DPPH, ascorbic acid, 5,5-Dithiobis-(2-nitrobenzoic acid) (DTNB), acetylthiocholine iodide (ATChI), 3-(4, 5-dimethylthiazol-2-yl)-2,5-diphenyl tetrazolium bromide (MTT), and anticancer agent cisplatin were purchased from Sigma-Aldrich (St. Louis, MO). Recombinant human BACE1, human AChE, and fluorogenic peptide substrate (FPS) McaSEVNLDAEFRK (Dnp) $\mathrm{RR}_{-} \mathrm{NH}_{2}$ were purchased from $R \& D$ system (Minneapolis, $M N$ ). Brain Heart Infusion (BHI) broth and Eggerth-Gagnon agar were purchased from Becton, Dickinson and Company (Sparks, MD) and Eiken Chemical (Tokyo, Japan), respectively. Minimum essential medium (MEM), RPMI 1640 medium, and fetal bovine serum (FBS) were purchased from Life Technologies (Grand Island, NY). All other reagents and chemicals used in the current study were available commercially, and with reagent-grade quality. 
Bee pollen samples and preparation of extract

Eighteen bee pollen samples (BP1-BP18) used for biological activities detection were purchased from bee keepers' shops in 16 different locations from 6 provinces of South Korea. The localities and coordinates of these bee pollen samples are listed in Table 1. One bee pollen sample of China was supplied from bee keeper in Weihai City, Shandong Province. Total nineteen bee pollen samples were extracted three times with $70 \%$ ethanol at room temperature for 2 days each, and filtered. The combined extract solutions were concentrated or dryness by rotary evaporation at $40{ }^{\circ} \mathrm{C}$ under reduced pressure according to the previous study [20]. The yield of concentrated extracts was obtained from 46.85 to $63.83 \%$ (Table 1). And the ethanol extracts were kept at $-20^{\circ} \mathrm{C}$ for further analysis.

\section{Palynological analysis of bee pollen}

Pollen analysis was based on the method reported previously [21]. $2 \mathrm{~g}$ of commercial bee pollen samples were added into $15 \mathrm{~mL}$ Falcon tube, followed with mixed with $70 \%$ ethanol to complete $13 \mathrm{~mL}$, and left for $30 \mathrm{~min}$. Then the samples were ultrasonication for $5 \mathrm{~min}$, and centrifuged for $3 \mathrm{~min}$ at $1500 \mathrm{rpm}$, and the sediment obtained was extracted with 70\% ethanol and ultrasonicated again. A solution of glycerol and distilled water $(\mathrm{v} /$ $\mathrm{v}=1: 1)$ was added to the sediment to make the volume
$13 \mathrm{~mL}$, and suspended, then left for about $30 \mathrm{~min}$. One drop of well-mixed bee pollen suspension was transferred on a microscope slide, covered with a cover slide and named, sealed with nail polish, and were analyzed under a microscope with a $400 \times$ magnification.

\section{Determination of total flavonoid and phenolic contents}

Total flavonoid contents in EBP samples were determined by $\mathrm{AlCl}_{3}$ colorimetric method based on our previous study [22]. The absorbance was determined at 435 $\mathrm{nm}$ using a VersaMax microplate reader with SoftMax Pro 5 Software. EBPs were evaluated at the final concentration of $1000 \mu \mathrm{g} \mathrm{mL}^{-\mathbf{1}}$. Quercetin $\left(0-12.5 \mu \mathrm{g} \mathrm{mL}^{-\mathbf{1}}\right)$ was applied as the standard, and the standard curve was $\mathrm{Y}=0.1774 \quad \mathrm{X}+0.0433$ (correlation coefficient $\mathrm{R}^{2}=$ $0.9995)$, where $X$ is the quercetin concentration in $\mu \mathrm{g}$ $\mathrm{mL}^{-1}$, and $\mathrm{Y}$ is the absorbance measured at $435 \mathrm{~nm}$. Total flavonoid contents were calculated by linear regression analysis based on the standard curve of quercetin and expressed as $\mathrm{mg}$ of quercetin equivalents (QE) per g of EBP samples concentrated and dry by rotary evaporation at $40^{\circ} \mathrm{C}$ under reduced pressure.

Total phenolic contents in EBP samples were determined based on Folin-Ciocalteu colorimetric method described previously [22]. The absorbance was determined at $735 \mathrm{~nm}$. EBPs were evaluated at the final concentration of $500 \mu \mathrm{g} \mathrm{m}^{-1}$. Gallic acid $(0-62.5 \mu \mathrm{g}$

Table 1 List of 18 bee pollen samples examined from 16 different locations of South Korea and the yield of their ethanol extract

\begin{tabular}{|c|c|c|c|}
\hline Sample & Locality & Coordinate & Yield (\%) \\
\hline BP1 & Yeoju (Gyeonggi) & $37^{\circ} 22^{\prime} 16.2^{\prime \prime} \mathrm{N} 127^{\circ} 35^{\prime} 45.2^{\prime \prime} \mathrm{E}$ & 56.07 \\
\hline BP2 & Yeoju (Gyeonggi) & $37^{\circ} 22^{\prime} 16.2^{\prime \prime} \mathrm{N} 127^{\circ} 35^{\prime} 45.2^{\prime \prime} \mathrm{E}$ & 58.65 \\
\hline BP3 & Yeoju (Gyeonggi) & $37^{\circ} 22^{\prime} 16.2^{\prime \prime} \mathrm{N} 127^{\circ} 35^{\prime} 45.2^{\prime \prime} \mathrm{E}$ & 56.48 \\
\hline BP4 & Gapyeong (Gyeonggi) & $37^{\circ} 49^{\prime} 53.55^{\prime \prime} \mathrm{N} 127^{\circ} 30^{\prime} 35.58^{\prime \prime} \mathrm{E}$ & 60.44 \\
\hline BP5 & Hwaseong (Gyeonggi) & $37^{\circ} 11^{\prime} 58.18^{\prime \prime} \mathrm{N} 126^{\circ} 49^{\prime} 52.28^{\prime \prime} \mathrm{E}$ & 49.20 \\
\hline BP6 & Uiwang (Gyeonggi) & $37^{\circ} 20^{\prime} 40.92^{\prime \prime} \mathrm{N} 126^{\circ} 58^{\prime} 5.92^{\prime \prime} \mathrm{E}$ & 61.18 \\
\hline BP7 & Paju (Gyeonggi) & $37^{\circ} 45^{\prime} 35.53^{\prime \prime} \mathrm{N} 126^{\circ} 46^{\prime} 48.64^{\prime \prime} \mathrm{E}$ & 63.83 \\
\hline BP8 & Samcheok-si (Gangwon) & $37^{\circ} 26^{\prime} 59.53^{\prime \prime} \mathrm{N} 129^{\circ} 9^{\prime} 54.74^{\prime \prime} \mathrm{E}$ & 59.06 \\
\hline BP9 & Yangyang-gun (Gangwon) & $38^{\circ} 4^{\prime} 31.41 " \mathrm{~N} 128^{\circ} 37^{\prime} 7.86^{\prime \prime} \mathrm{E}$ & 62.80 \\
\hline BP10 & Goryeong-gun (Gyeongsangbuk) & $35^{\circ} 43^{\prime} 34.11 " \mathrm{~N} 128^{\circ} 15^{\prime} 46.63^{\prime \prime} \mathrm{E}$ & 58.93 \\
\hline BP11 & Andong (Gyeongsangbuk) & $36^{\circ} 34^{\prime} 6.08^{\prime \prime} \mathrm{N} 128^{\circ} 43^{\prime} 45.69^{\prime \prime} \mathrm{E}$ & 46.85 \\
\hline BP12 & Gunwi-gun (Gyeongsangbuk) & $36^{\circ} 14^{\prime} 34.25^{\prime \prime} \mathrm{N} 128^{\circ} 34^{\prime} 21.99^{\prime \prime} \mathrm{E}$ & 54.73 \\
\hline BP13 & Jeongeup (Jeollabuk) & $35^{\circ} 34^{\prime} 11.59^{\prime \prime} \mathrm{N} 126^{\circ} 51^{\prime} 21.22^{\prime \prime} \mathrm{E}$ & 55.74 \\
\hline BP14 & Sancheong-gun (Gyeongsangnam) & $35^{\circ} 24^{\prime} 56.12^{\prime \prime} \mathrm{N} 128^{\circ} 52^{\prime} 24.59^{\prime \prime} \mathrm{E}$ & 51.68 \\
\hline BP15 & Yeosu (Jeollanam) & $34^{\circ} 45^{\prime} 37.35^{\prime \prime} \mathrm{N} 127^{\circ} 39^{\prime} 44.00^{\prime \prime} \mathrm{E}$ & 54.33 \\
\hline BP16 & Jindo (Jeollanam) & $34^{\circ} 29^{\prime} 12.74^{\prime \prime} \mathrm{N} 126^{\circ} 15^{\prime} 48.55^{\prime \prime} \mathrm{E}$ & 55.40 \\
\hline BP17 & Damyang-gun (Jeollanam) & $35^{\circ} 19^{\prime} 16.10^{\prime \prime} \mathrm{N} 126^{\circ} 59^{\prime} 17.40^{\prime \prime} \mathrm{E}$ & 61.32 \\
\hline BP18 & Hampyeong (Jeollanam) & $35^{\circ} 03^{\prime} 57.38^{\prime \prime} \mathrm{N} 126^{\circ} 30^{\prime} 59.59^{\prime \prime} \mathrm{E}$ & 58.77 \\
\hline CNBP & Weihai (Shandong) & $36^{\circ} 41^{\prime} 38.66^{\prime \prime} \mathrm{N} 121^{\circ} 11^{\prime} 3.84^{\prime \prime} \mathrm{E}$ & 54.96 \\
\hline
\end{tabular}


$\mathrm{mL}^{-\mathbf{1}}$ ) was used as the standard, and the standard curve was $Y=0.2265 X+0.0888\left(R^{2}=0.9950\right)$, where $X$ is the gallic acid concentration in $\mu \mathrm{g} \mathrm{mL^{-1 }}$ and $\mathrm{Y}$ is the absorbance of reaction mixture at $735 \mathrm{~nm}$. Total polyphenol contents were calculated according to linear regression analysis based on the standard curve, and expressed as $\mathrm{mg}$ of gallic acid equivalents (GAE) per $\mathrm{g}$ of EBP samples prepared by the above method.

\section{DPPH radical scavenging assay}

Antioxidants with natural origin, particularly in food applications, are considered to be widely used to prevent disease and healthy maintenance [23]. Bee pollen, or as a dietary supplement, is widely intake in daily life. Antioxidant activity of EBP was assessed by DPPH radical scavenging assay according to the method described in our previous study [22]. In order to obtain the $\mathrm{EC}_{50}$ value of radical scavenging activity of DPPH for each EBP sample, seven concentrations were applied with ranging from 15.6 to $2000 \mu \mathrm{g} \mathrm{mL}^{-1}$. Ascorbic acid was used as a positive control and similarly formulated. The radical scavenging ability of each EBP sample was calculated according to the equation: \% $\mathrm{DPPH}$ free radical scavenging activity $=\left(1-A_{s} / A_{c}\right) \times 100$, where $A_{c}$ is the absorbance of the control and $A_{s}$ is the absorbance of the sample.

\section{Fluorescence resonance energy transfer enzyme assay}

In the amyloid precursor protein (APP) amyloidgenic pathway, BACE1 plays an important role in the generation of $\beta$-amyloid $(A \beta)$ that the main composition of amyloid plaque related to the pathogenesis of $A D$ [24]. BACE1 inhibitor has been regarded as a therapeutic target in reducing $A \beta$ production. The BACE1 inhibitory activity of all EBP samples was evaluated by the fluorescence resonance energy transfer (FRET) enzyme assay method according to our previous studies [22, 25]. In order to get the $\mathrm{EC}_{50}$ of BACE1 inhibitory activity, seven concentrations were applied with ranging from 15.6 to $2000 \mu \mathrm{g} \mathrm{mL}^{-1}$. The inhibition percentage of EBP sample against human BACE1 was calculated based on the formula: \% inhibition $=100-\left[\left(\mathrm{F}_{\mathrm{S}}-\mathrm{F}_{\mathrm{S} 0}\right) /\left(\mathrm{F}_{\mathrm{C}}-\mathrm{F}_{\mathrm{C} 0}\right)\right] \times$ 100 , where $F_{S}$ and $F_{S 0}$ are the fluorescence indensity of samples at $60 \mathrm{~min}$ and zero time, and $\mathrm{F}_{\mathrm{C}}$ and $\mathrm{F}_{\mathrm{C}}$ are that of control at $60 \mathrm{~min}$ and zero time, respectively.

\section{Acetylcholinesterase (AChE) inhibition assay}

Acetylcholine (ACh), as a neurotransmitter plays an important role in learning and memory processes [26]. The AChE exists in the synaptic cleft of neurons and hydrolyzes ACh to reduce the level of it. In the brain of $\mathrm{AD}$, the more decreased $\mathrm{ACh}$ level induced the memory deficits. AChE inhibitor increased the concentration of $\mathrm{ACh}$ in the neuron synapses by binding to the enzyme
[27]. The AChE inhibition assay procedure was performed using the recombinant human AChE according to the manufacture's protocol as described in our previous study [22]. The inhibition percentage of EBP sample against human $\mathrm{AChE}$ was calculated based on the equation: \% inhibition $=100-\left[\left(\mathrm{A}_{\mathrm{S}}-\mathrm{A}_{\mathrm{SO}}\right) /\left(\mathrm{A}_{\mathrm{C}}-\mathrm{A}_{\mathrm{CO}}\right)\right] \times$ 100 , where $A_{S}$ and $A_{S 0}$ are the absorbance of samples at 60 min and zero time, and $A_{C}$ and $A_{C 0}$ are that of control at $60 \mathrm{~min}$ and 0 time, respectively.

\section{Human intestinal bacterial strains and growth inhibitory assay}

It is well known that the intestinal microorganisms in human gastrointestinal tract plays important role in modulating various physiologic and metabolic function for human health $[28,29]$. Our previous study has reported that bee product (bee propolis) collected from South Korea have beneficial effects on human intestinal bacteria [22]. There are a few literatures that deal with the relationship between bee pollen and human intestinal bacteria. In our study, to assess the effect of EBP samples on human intestinal bacteria, beneficial six lactic acid-producing bacteria employed in the food industry including Bifidobacterium bifidum ATCC 29521, Bifidobacterium breve ATCC 15700, Bifidobacterium infantis ATCC 25962, Bifidobacterium longum ATCC 15707, Lactobacillus acidophilus ATCC 4356, and Lactobacillus casei ATCC 393, and an acidulating bacterium (Clostridium butyricum ATCC 25779), as well as four harmful bacteria including Clostridium difficile ATCC 9689, Clostridium paraputrificum ATCC 25780, Clostridium perfringens ATCC 13124, Staphylococcus aureus ATCC 12600, and two nonpathogenic bacteria (Bacteroides fragilis ATCC 25285, and Escherichia coli ATCC 11775) were tested in the current study. All of these strains were purchased form American type culture collection (ATCC). Stock cultures of the bacterial strains were prepared with $\mathrm{BHI}$ broth ( $\mathrm{pH} 7.6)$ containing $25 \%$ glycerol $(\mathrm{v} / \mathrm{v})$ and stored at $-70^{\circ} \mathrm{C}$. The cultures of Staphylococcus aureus ATCC 12600 and Escherichia coli ATCC 11775 were incubated at $37^{\circ} \mathrm{C}$ for $24 \mathrm{~h}$ under aerobic condition, while the cultures of the other bacterial strains were incubated at $37^{\circ} \mathrm{C}$ for $24 \mathrm{~h}$ in an atmosphere of $5 \% \mathrm{H}_{2}, 15 \% \mathrm{CO}_{2}$, and $80 \% \mathrm{~N}_{2}$ in a FA-6 anaerorator (serial no. 98072851, Hirayama, Tokyo, Japan) according to the previous study [22]. The minimal inhibitory concentrations (MIC) of all EBP samples toward the organisms were determined by a microtiter plate-based bioassay in sterile 96 well plates, as described previously [30].

\section{Cancer cell lines and cell proliferation assay}

Bee pollen as a natural and healthy food, can improve human immunity. Previous study has demonstrated 
pollen could markedly suppress tumor growth [13]. However, this is few study illuminated the anti-cancer effects of bee pollen collected from South Korea. There are five human cancer cell lines used in the present study including PC-3 (human prostate adenocarcinoma cell line), MCF-7 (human breast adenocarcinoma cell line), AGS (human stomach cancer), and NCI-H727 (human lung carcinoma cell line) supplied by the Korean Cell Line Bank (Seoul, South Korea); A549 (human lung carcinoma cell line) purchased from the American Type Culture Collection (ATCC) (Manassas, VA). The PC-3, MCF-7, NCI-H727, and AGS cell lines were cultured with RPMI 1640 containing 10\% FBS and 1\% antibiotic, whereas A549 cell line was cultured with MEM containing 10\% FBS, $1 \%$ antibiotic solution, and $1 \%$ glutamine. Cells were grown in SPL Life Science cell culture dishes under $5 \% \mathrm{CO}_{2}$ and $95 \%$ air at $37{ }^{\circ} \mathrm{C}$. The MTT assay was examined to evaluate the antiproliferative activity of all EBP samples toward the above five the human cancer cell lines as described previously [31]. To obtain the $\mathrm{IC}_{50}$ value of antiproliferative activity of each EBP sample toward five human cancer cell lines, six concentrations ranging from 0.78 to $25 \mathrm{mg} \mathrm{mL}^{-1}$ were determined. The cell treated by different concentration of EBP samples were cultured for $48 \mathrm{~h}$. The cultured plates were then washed with $100 \mu \mathrm{L}$ PBS, followed by adding $100 \mu \mathrm{L}$ medium containing $0.05 \%$ MTT and then incubated for $4-6 \mathrm{~h}$ at the same condition stated previously. Then MTT solution was removed and $200 \mu \mathrm{L}$ DMSO was added to each well. Finally, the plate was shaken for 10 min at room temperature to dissolve the purple formazan crystals formed. The absorbance values were recorded at a $560 \mathrm{~nm}$ and a $670 \mathrm{~nm}$ reference by a VersaMax microplate reader stated above. Cisplatin served as positive controls and was similarly prepared. The inhibition of EBP sample to cells was calculated according to the following formula: \% Inhibition $=[1$ $\left.\left(A_{T} / A_{C}\right)\right] \times 100$, where $A_{T}$ is the absorbance value of EBP sample treated, and $\mathrm{A}_{\mathrm{C}}$ for control.

\section{Statistical analysis}

All the determination was carried out in at least triplicate. All the results were expressed as mean \pm standard error (SE) of samples with three independent experiments. In each parameter, the differences between bee pollen samples were analyzed using one-way analysis of variance (ANOVA) followed by Bonferroni multiplecomparison method using SPSS 16.0 program (SPSS Inc. Chicago, IL, USA).

\section{Results}

\section{Palynological identification of bee pollen samples}

On the basis of palynological analysis, 4 of 18 pollen samples from South Korea (BP3, BP4, BP13 and BP15) were found to be monofloral and presented four dominant pollen types: Quercus palustris, Actinidia arguta, Robinia pseudoacacia, and Amygdalus persica. One sample (BP12) was found to be bifloral, relating to Quercus palustris and Robinia pseudoacacia. Most of the pollen samples, including BP1, BP2, BP5, BP6, BP7, BP8, BP9, BP10, BP11, BP14, BP16, BP17 and BP18, were found to be heterofloral. As a previous study reported, pollen samples with pollen type frequencies higher than $45 \%$ were considered the predominant pollen types, $16-45 \%$ frequency were considered secondary pollen types, and $3-15 \%$ were considered important minor pollen types [20]. In the current study, we found that Quercus palustris was dominant in the BP1, BP2, BP4, BP8, BP12, and BP15 samples, Actinidia arguta was dominant in the BP3 sample, Amygdalus persica was dominant in the BP11 sample, and Robinia pseudoacacia was dominant in the BP13 sample. However, no dominant pollen was observed in the BP5, BP6, BP7, BP9, BP10, BP14, BP16, BP17, and BP18 samples (Table 2).

\section{Total flavonoids and phenolic contents of bee pollen samples}

The total flavonoid and phenolic compound contents of 18 EBP samples collected from 16 different regions of South Korea were compared with one Chinese EBP sample (Fig. 1). The total flavonoid contents ranged from 1.84 to $6.66 \mathrm{mg}$ of quercetin equivalents per gram of EBP, while the flavonoid content of the Chinese bee pollen was $2.98 \mathrm{mg}$. Ethanol extract samples of BP7, BP13, BP2, BP9 and BP5 showed higher flavonoid contents (6.66-5.00 mg QE/g EBP) than those of other samples. The samples with the lowest total flavonoid contents were BP3 and BP11, with a value of $1.84 \mathrm{mg}$ QE/g EBP. This result indicated that pollen predominantly from the plant species Robinia pseudoacacia contained a higher amount of flavonoids than that contained in pollens predominantly from Actinidia arguta and Amygdalus persica. The total phenolic compound contents of Korean EBP samples ranged from 6.33 to $37.55 \mathrm{mg}$ of gallic acid equivalents per gram of EBP and were higher than the phenolic acid content of the Chinese sample $(0.37 \mathrm{mg})$. Similar results were found in the phenolic compound content assay, in which the EBP7 and EBP13 samples presented higher phenolic compound contents than those of phenolic compounds in pollen from other regions, with values of 37.55 and $22.91 \mathrm{mg}$ GAE/g EBP, respectively. The total flavonoids of the BP3 and BP11 samples, with values of 6.33 and $13.28 \mathrm{mg} \mathrm{GAE} / \mathrm{g} \mathrm{EBP}$, respectively, were the lowest, which demonstrated that pollen grains predominantly from the plant species Robinia pseudoacacia possess higher amounts of flavonoids than those of flavonoids in 
Table 2 Comparison of 18 pollen load samples from Apis mellifera evaluated by a pool of $2 \mathrm{~g}$ of each bath. Only the pollen sample with frequency $>3 \%$ were considered

\begin{tabular}{|c|c|c|c|}
\hline Sample & Time of collection & Pollen type identification & Evaluation of pollen sample \\
\hline$\overline{\mathrm{BP} 1}$ & May & $\begin{array}{l}\text { Quercus palustris }(+++) \\
\text { Robinia pseudoacacia }(++) \text {, } \\
\text { unknown }(+)\end{array}$ & Heterofloral with domain of Quercus palustris \\
\hline BP2 & May & $\begin{array}{l}\text { Quercus palustris }(+++), \\
\text { Robinia pseudoacacia }(++)\end{array}$ & Heterofloral with domain of Quercus palustris \\
\hline BP3 & May & Actinidia arguta $(++++)$ & Monofloral of Actinidia arguta \\
\hline BP4 & May & Quercus palustris $(++++)$ & Monofloral of Quercus palustris \\
\hline BP5 & & $\begin{array}{l}\text { Quercus palustris }(++), \\
\text { Robinia pseudoacacia }(++), \\
\text { unknown }(+), \text { Pinus }(+)\end{array}$ & Heterofloral \\
\hline BP6 & June & $\begin{array}{l}\text { Robinia pseudoacacia }(++), \\
\text { Quercus palustris }(++), \\
\text { unknown }(+)\end{array}$ & Heterofloral \\
\hline BP7 & June & $\begin{array}{l}\text { Robinia pseudoacacia }(++), \\
\text { Quercus palustris }(++), \\
\text { Pinus (+) }\end{array}$ & Heterofloral \\
\hline BP8 & May & $\begin{array}{l}\text { Quercus palustris }(+++), \\
\text { Robinia pseudoacacia }(++), \\
\text { unknown }(+)\end{array}$ & Heterofloral with domain of Quercus palustris \\
\hline BP9 & May & $\begin{array}{l}\text { Quercus palustris (++), } \\
\text { Robinia pseudoacacia }(++), \\
\text { Actinidia arguta }(++), \\
\text { unknown (+), Pinus (+) }\end{array}$ & Heterofloral \\
\hline BP10 & May & $\begin{array}{l}\text { Quercus palustris (++), } \\
\text { Robinia pseudoacacia }(++), \\
\text { Actinidia arguta }(++), \\
\text { unknown }(+), \text { Pinus (+) }\end{array}$ & Heterofloral \\
\hline BP11 & April & $\begin{array}{l}\text { Amygdalus persica }(+++), \\
\text { Robinia pseudoacacia }(++) \\
\text { Actinidia arguta }(++), \\
\text { Taraxacum mongolicum (+) }\end{array}$ & Heterofloral with domain of Amygdalus persica \\
\hline BP12 & April & $\begin{array}{l}\text { Quercus palustris }(+++), \\
\text { Robinia pseudoacacia }(++)\end{array}$ & Bifloral of Quercus palustris (dominant) and Robinia pseudoacacia \\
\hline BP13 & June & Robinia pseudoacacia $(++++)$ & Monofloral of Robinia pseudoacacia \\
\hline BP14 & May & $\begin{array}{l}\text { Quercus palustris (++), } \\
\text { Robinia pseudoacacia }(++), \\
\text { Actinidia arguta }(+)\end{array}$ & Heterofloral \\
\hline BP15 & May & Quercus palustris $(++++)$ & Monofloral of Quercus palustris \\
\hline BP16 & May & $\begin{array}{l}\text { Quercus palustris }(++), \\
\text { Robinia pseudoacacia }(++), \\
\text { Actinidia arguta }(++), \\
\text { Pinus }(+)\end{array}$ & Heterofloral \\
\hline BP17 & May & $\begin{array}{l}\text { Robinia pseudoacacia }(++), \\
\text { Actinidia arguta }(++), \\
\text { Pinus }(+)\end{array}$ & Heterofloral \\
\hline BP18 & April & $\begin{array}{l}\text { Amygdalus persica }(++), \\
\text { Robinia pseudoacacia }(++), \\
\text { Actinidia arguta }(++)\end{array}$ & Heterofloral \\
\hline CNBP & August & Nelumbo nucifera $(++++)$ & Monofloral of Nelumbo nucifera \\
\hline
\end{tabular}

pollen grains predominantly from Actinidia arguta and Amygdalus persica. The sample collected from China had a lower phenolic compound content than those of all the Korea BP samples, indicating that pollen from the plant species of Nelumbo nucifera contains low amounts of phenolic compounds. In addition, BP showed different 

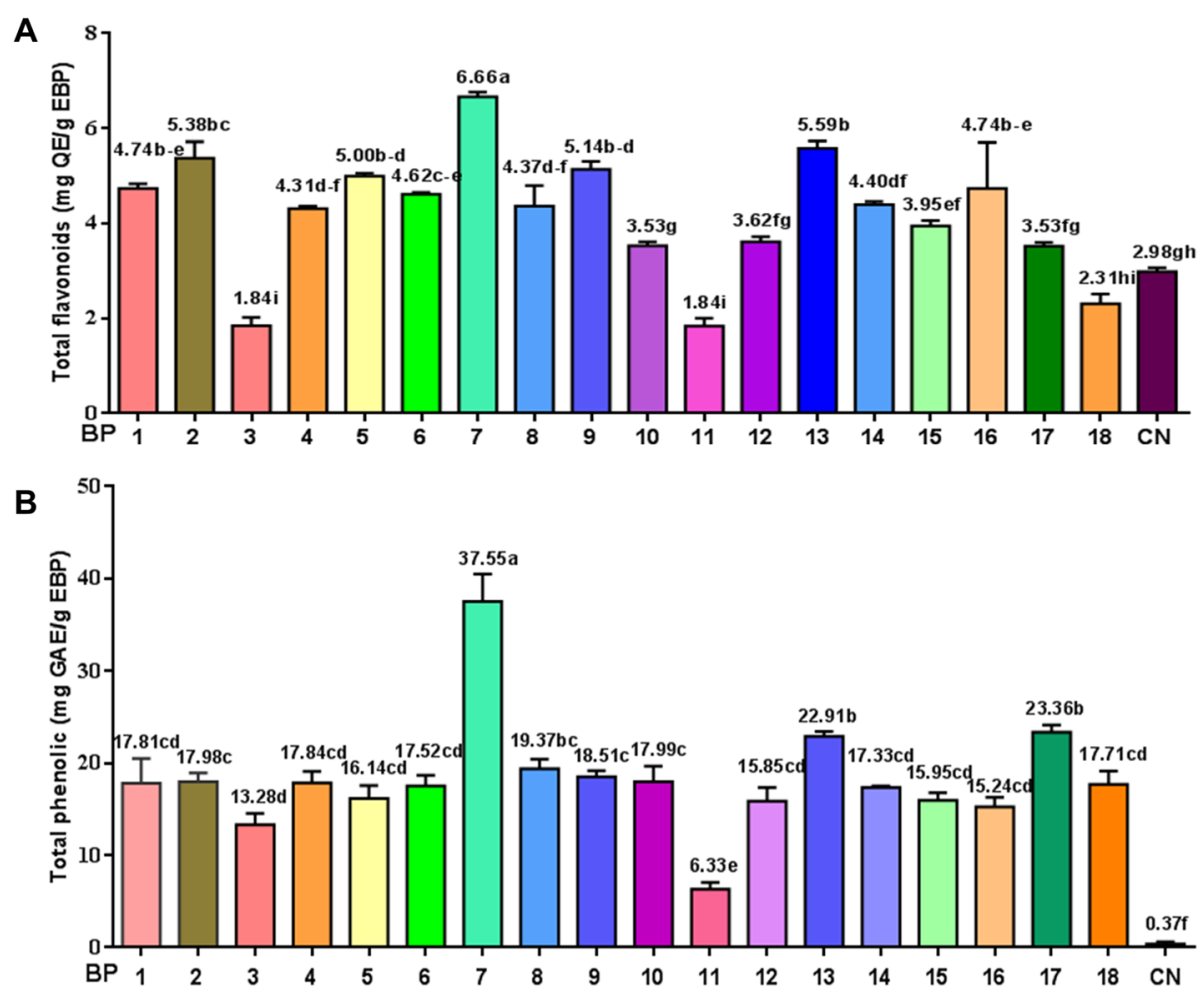

Fig. 1 Total flavonoids (a) and phenolic content (b) in 18 different EBP samples from 16 different locations of South Korea, and 1 Chinese bee pollen ethanol extracts (mean \pm SD). QE: Quercetin equivalent; GAE: gallic acid equivalent; EBP: ethanol extract of bee pollen. Means followed by the same letter in the column are not significantly different $(P=0.05$, Bonferroni method)

amounts of phenolic and flavonoid contents varying from different geographical origins, which was consistent with a previous report that bee pollen collected by bees shows different contents of polyphenols due not only to its botanical origin but also to its geographical origin [17].

\section{DPPH free radical scavenging activity}

Antioxidants of natural origin, particularly in food applications, are considered to be widely used to prevent disease and health maintenance [23]. The DPPH free radical scavenging assay system was used to test the antioxidant activity of EBP samples. The scavenging activity of the free DPPH radical was presented in terms of $\mathrm{EC}_{50}$, and the $\mathrm{EC}_{50}$ values of each EBP sample are listed in (Table 3). Based on the $\mathrm{EC}_{50}$ values, 16 Korean EBP samples showed antioxidant activity with $\mathrm{EC}_{50}$ values ranging from 292.0 to $673.9 \mu \mathrm{g} \mathrm{mL}^{-1}$, which were lower than that of the positive ascorbic acid control $\left(\mathrm{EC}_{50}, 13.8 \mu \mathrm{g} \mathrm{mL} \mathrm{m}^{-1}\right)$. Sample BP18 presented the highest antioxidant activity, with an $\mathrm{EC}_{50}$ value of $292.0 \mu \mathrm{g} \mathrm{mL}^{-1}$, followed by sample BP7, with an $\mathrm{EC}_{50}$ value of $319.6 \mu \mathrm{g} \mathrm{m}^{-1}$. The ethanol extracts of samples BP3 and BP11 and the Chinese sample presented low antioxidant activity with $\mathrm{EC}_{50}$ values higher than $1 \mathrm{mg} \mathrm{mL}^{-1}$. This indicates that BP predominantly from the plant species Actinidia arguta presented a lower DPPH radical scavenging ability than that BP predominantly from Amygdalus persica, Robinia pseudoacacia, and Quercus palustris. BP11 and BP18 were observed to be similar according to the palynological analysis, but they were found to have significant differences in terms of antioxidant effects. This indicated that a small number of pollen grains in the BP18 sample rather than in the BP11 may contribute to its DPPH radical scavenging ability. In addition to its botanical origin, other factors, including geographical origin and climate, affect BP antioxidant ability.

\section{In vitro human BACE1 inhibitory activity}

BACE1 is well known as one of the most important APP cleaving enzymes in AD pathology. BACE1 inhibitors have been regarded as therapeutic targets in reducing $\mathrm{A} \beta$ production, thereby alleviating $\mathrm{AD}$. There is no report available demonstrating the relationship between pollen samples and BACE1 activity. In the current study, we first evaluated the potent BACE1 inhibitory activity 
Table 3 Antioxidant and BACE1 inhibitory activity of 18 bee pollen samples examined from 16 different locations of South Korea and 1 sample from China

\begin{tabular}{|c|c|c|}
\hline \multirow{2}{*}{$\begin{array}{l}\text { Sample } \\
\text { No. }\end{array}$} & \multirow{2}{*}{$\begin{array}{l}\mathrm{DPPH} \\
\mathrm{EC}_{50}, \mu \mathrm{g} / \mathrm{mL}\end{array}$} & \multirow{2}{*}{$\begin{array}{l}\text { BACE-1 } \\
\mathrm{EC}_{50}, \mu \mathrm{g} / \mathrm{mL}\end{array}$} \\
\hline & & \\
\hline BP1 & $544.0 \pm 53.22 c$ & $369.6 \pm 0.58 c$ \\
\hline BP2 & $450.1 \pm 10.45 b c$ & $642.1 \pm 6.81 \mathrm{~g}$ \\
\hline BP3 & $>1000$ & $669.5 \pm 3.02 \mathrm{~g}$ \\
\hline BP4 & $673.9 \pm 20.99 d$ & $1008.9 \pm 8.09 k$ \\
\hline BP5 & $525.7 \pm 63.87 c$ & $497.5 \pm 5.90 \mathrm{e}$ \\
\hline BP6 & $408.0 \pm 24.92 \mathrm{abc}$ & $414.7 \pm 10.30 d$ \\
\hline BP7 & $319.6 \pm 15.48 a b$ & $236.0 \pm 3.01 a$ \\
\hline BP8 & $452.7 \pm 28.49 b c$ & $635.6 \pm 8.65 \mathrm{~g}$ \\
\hline BP9 & $403.7 \pm 11.91 \mathrm{abc}$ & $881.1 \pm 5.28 j$ \\
\hline BP10 & $534.0 \pm 34.03 c$ & $1491.7 \pm 17.95 \mathrm{~m}$ \\
\hline BP11 & $>1000$ & $760.5 \pm 6.99 h$ \\
\hline BP12 & $403.2 \pm 21.83 a b c$ & $1083.7 \pm 13.37 \mid$ \\
\hline BP13 & $447.3 \pm 31.17 \mathrm{bc}$ & $1004.1 \pm 7.49 k$ \\
\hline BP14 & $401.0 \pm 30.27 a b c$ & $511.0 \pm 14.13 \mathrm{e}$ \\
\hline BP15 & $487.5 \pm 32.40 c$ & $851.2 \pm 15.77 i$ \\
\hline BP16 & $483.9 \pm 46.78 c$ & $584.3 \pm 17.04 f$ \\
\hline BP17 & $408.4 \pm 15.85 a b c$ & $496.2 \pm 10.26 e$ \\
\hline BP18 & $292.0 \pm 13.05 a$ & $830.1 \pm 4.47 i$ \\
\hline CNBP & $>1000$ & $322.7 \pm 8.00 b$ \\
\hline
\end{tabular}

CNBP Chinese bee pollen

Different letter $(\mathrm{a}-\mathrm{I})$ in the same row indicate significant difference $(p<0.05)$

of 18 Korean bee pollen samples in vitro according to the FRET enzyme assay method. As the results showed, 18 Korean bee pollen samples exhibited anti-BACE1 ability, with $\mathrm{EC}_{50}$ values ranging from 236.0 to $1492 \mu \mathrm{g} \mathrm{mL}^{-1}$ (Table 3). Sample BP7 showed the highest activity $\left(\mathrm{EC}_{50}\right.$, $236.0 \mu \mathrm{g} \mathrm{mL}^{-1}$ ), followed by samples BP1 and BP6 with $\mathrm{EC}_{50}$ values of 369.6 and $414.7 \mu \mathrm{g} \mathrm{mL}^{-1}$, respectively. BP13, BP4, BP12, and BP10 showed lower inhibitory activities than those of other samples, with $\mathrm{EC}_{50}$ values of 1004, 1009, 1084, and $1492 \mu \mathrm{g} \mathrm{mL}^{-1}$, respectively, which were higher than $1000 \mu \mathrm{g} \mathrm{mL}^{-1}$. These results demonstrated that the heterofloral pollen samples exhibited better anti-BACE1 activity than those of monofloral pollen. However, the Chinese monofloral bee pollen, with an $\mathrm{EC}_{50}$ of $322.7 \mu \mathrm{g} \mathrm{mL}^{-1}$, indicated that Nelumbo nucifera pollen type was found to be a better candidate for antiBACE1 than monofloral Quercus palustris, Actinidia arguta, Robinia pseudoacacia, and Amygdalus persica pollens. In addition, the bee pollen with Robinia pseudoacacia as the dominant source possessed a greater potential inhibitory ability against BACE1 than those of pollen with Quercus palustris as the predominant origin.

\section{Human AChE inhibitory activity}

AChE inhibitors can increase the concentration of $\mathrm{ACh}$ in neuronal synapses in AD to promote damaged neurological recovery [27]. Some bee products, such as propolis, have been discovered to possess AChE inhibitory activities from different locations in Morocco and South Korea [22, 32]. However, few studies have reported the inhibitory activity of pollen against AChE. In the current study, the inhibitory activity of bee pollen against human AChE was assessed. However, the $\mathrm{EC}_{50}$ values were higher than $2 \mathrm{mg} \mathrm{mL}^{-1}$, indicating that potential inhibitory activities were not strong in the 18 EBP samples from 16 different regions in South Korea.

\section{Human intestinal bacteria growth inhibitory activity}

Bee pollen extracts have been previously reported to possess antimicrobial activity [10,11]. The growth inhibitory activity of human intestinal bacteria was assessed in our study. The 18 EBP samples from Korea did not inhibit beneficial bacteria, including six lactic acid-producing bacteria (Bifidobacterium bifidum ATCC 29521, Bifidobacterium breve ATCC 15700, Bifidobacterium infantis ATCC 25962, Bifidobacterium longum ATCC 15707, Lactobacillus acidophilus ATCC 4356, and Lactobacillus casei ATCC 393) and an acidulating bacterium (Clostridium butyricum ATCC 25779), and did not show potent strong inhibitory activity toward two nonpathogenic bacteria (Bacteroides fragilis ATCC 25285 and Escherichia coli ATCC 11775). The MIC values of the 18 Korean and 1 Chinese bee pollen samples were $>50 \mathrm{mg} \mathrm{mL}^{-1}$ toward four harmful bacteria (Clostridium difficile ATCC 9689, Clostridium paraputrificum ATCC 25780, Clostridium perfringens ATCC 13124, and Staphylococcus aureus ATCC 12600). There is limited literature on the antimicrobial activity of bee pollen in South Korea. The above results proved that the 18 bee pollen samples collected from South Korea in our study did not show considerable effects on beneficial, nonpathogenic, or harmful bacteria.

\section{Antiproliferative effect on cancer cell lines}

There are few reports about the antiproliferative activity of bee pollen toward human cancer cell lines. Bee pollen polysaccharides from Rosa rugosa have been observed to possess antiproliferative effects on the human colorectal adenocarcinoma cell lines HT-29 and HCT116 [13]. In addition, bee pollen extracts from different solvents showed different antiproliferative activities against BT474, HepG2, KATO-III and SW620 cells [33]. In this study, the antiproliferative effect toward five human cancer cell lines of all 18 Korean EBP samples and 1 Chinese sample was measured and compared with that of the commercial anticancer agent cisplatin (Table 4). Based 
Table 4 Antiproliferative activity of 18 different EBP samples from 16 regions of South Korea pollen ethanol extracts toward 5 cancer cell lines

\begin{tabular}{|c|c|c|c|c|c|}
\hline Sample & PC-3 cell & MCF-7 cell & A549 cell & $\mathrm{NCl}-\mathrm{H} 727$ & AGS cell \\
\hline & $\mathrm{IC}_{50}, \mathrm{mg} / \mathrm{mL}$ & $\mathrm{IC}_{50}, \mathrm{mg} / \mathrm{mL}$ & $\mathrm{IC}_{50}, \mathrm{mg} / \mathrm{mL}$ & $\mathrm{IC}_{50}, \mathrm{mg} / \mathrm{mL}$ & $\mathrm{IC}_{50}, \mathrm{mg} / \mathrm{mL}$ \\
\hline BP1 & $6.6 \pm 0.32 \mathrm{def}$ & $1.5 \pm 0.17 a b$ & $15.1 \pm 0.14 \mathrm{cde}$ & $4.6 \pm 0.54 \mathrm{bcd}$ & $6.8 \pm 0.05 c$ \\
\hline BP2 & $5.2 \pm 0.21 \mathrm{bcd}$ & $1.4 \pm 0.13 a$ & $15.3 \pm 0.05 \mathrm{cde}$ & $2.7 \pm 0.27 a$ & $6.9 \pm 0.09 c$ \\
\hline BP3 & $7.0 \pm 1.36 \mathrm{ef}$ & $12.7 \pm 0.55 j$ & $>25$ & $6.7 \pm 0.79 \mathrm{efg}$ & $6.7 \pm 0.05 c$ \\
\hline BP4 & $14.4 \pm 0.07 i$ & $5.1 \pm 0.50 f g h$ & $18.5 \pm 2.31 \mathrm{ef}$ & $9.6 \pm 0.24 h$ & $6.8 \pm 0.04 c$ \\
\hline BP5 & $2.9 \pm 0.28 a$ & $3.7 \pm 0.24 \mathrm{cdef}$ & $8.0 \pm 0.33 b$ & $3.2 \pm 0.08 \mathrm{ab}$ & $3.4 \pm 0.09 a b$ \\
\hline BP6 & $9.9 \pm 0.61 \mathrm{~h}$ & $2.8 \pm 0.13 \mathrm{abcde}$ & $8.8 \pm 0.46 b$ & $3.9 \pm 0.05 a b c$ & $3.4 \pm 0.04 a b$ \\
\hline BP7 & $4.0 \pm 0.09 a b c$ & $0.9 \pm 0.11 a$ & $5.0 \pm 0.18 a$ & $4.8 \pm 0.29 \mathrm{bcd}$ & $2.5 \pm 0.15 a b$ \\
\hline BP8 & $2.7 \pm 0.29 a$ & $5.9 \pm 0.55 h i$ & $13.2 \pm 0.59 \mathrm{~cd}$ & $5.4 \pm 0.22 \mathrm{cde}$ & $4.1 \pm 0.20 b$ \\
\hline BP9 & $3.8 \pm 0.31 \mathrm{ab}$ & $3.4 \pm 0.51 \mathrm{bcdef}$ & $9.1 \pm 0.68 b$ & $3.4 \pm 0.24 a b$ & $3.4 \pm 0.06 a b$ \\
\hline BP10 & $6.5 \pm 0.45$ def & $3.5 \pm 0.54 \mathrm{cdef}$ & $14.8 \pm 0.38 \mathrm{cde}$ & $9.2 \pm 0.37 \mathrm{~h}$ & $6.1 \pm 0.59 c$ \\
\hline BP11 & $3.3 \pm 0.12 \mathrm{ab}$ & $1.9 \pm 0.20 \mathrm{abc}$ & $12.6 \pm 0.38 c$ & $5.2 \pm 0.46 \mathrm{cde}$ & $2.4 \pm 0.16 a b$ \\
\hline BP12 & $3.4 \pm 0.19 a b$ & $4.5 \pm 0.64 \mathrm{efgh}$ & $14.9 \pm 1.56 \mathrm{cde}$ & $17.7 \pm 0.33 k$ & $8.7 \pm 1.64 d$ \\
\hline BP13 & $8.9 \pm 0.09 \mathrm{gh}$ & $6.8 \pm 0.46 i$ & $17.0 \pm 0.63 \mathrm{def}$ & $10.9 \pm 0.17 i$ & $8.0 \pm 0.27 \mathrm{~cd}$ \\
\hline BP14 & $6.9 \pm 0.08 \mathrm{def}$ & $3.9 \pm 0.40$ defg & $17.8 \pm 0.14 \mathrm{ef}$ & $7.1 \pm 0.21 \mathrm{fg}$ & $6.1 \pm 0.01 c$ \\
\hline BP15 & $8.1 \pm 0.33 \mathrm{fg}$ & $5.5 \pm 0.93 \mathrm{ghi}$ & $>25$ & $12.8 \pm 0.79 j$ & $6.7 \pm 0.13 c$ \\
\hline BP16 & $5.7 \pm 0.6719 \mathrm{cde}$ & $2.4 \pm 0.20 \mathrm{abcd}$ & $20.6 \pm 1.13 f$ & $11.5 \pm 0.40 i$ & $7.2 \pm 0.07 c$ \\
\hline BP17 & $4.2 \pm 0.18 \mathrm{abc}$ & $2.3 \pm 0.21 \mathrm{abcd}$ & $12.0 \pm 0.35 c$ & $6.0 \pm 0.57 \mathrm{dfe}$ & $6.0 \pm 0.20 c$ \\
\hline BP18 & $4.3 \pm 0.14 a b c$ & $2.3 \pm 0.06 \mathrm{abcd}$ & $19.9 \pm 1.91 f$ & $7.8 \pm 0.38 \mathrm{~g}$ & $3.7 \pm 0.07 b$ \\
\hline CNBP & $3.3 \pm 0.18 \mathrm{ab}$ & $2.8 \pm 0.31$ abcde & $16.1 \pm 0.11 \mathrm{cde}$ & $2.8 \pm 0.11 a$ & $1.8 \pm 0.04 a$ \\
\hline Cisplatin & $0.081 \pm 0.0053$ & $0.005 \pm 0.0022$ & $0.022 \pm 0.0006$ & $0.004 \pm 0.0003$ & $0.035 \pm 0.0015$ \\
\hline
\end{tabular}

on the $\mathrm{IC}_{50}$ value, the antiproliferative effect on the PC3 cell line ranged from 2.7 to $14.4 \mathrm{mg} \mathrm{mL}^{-1}$. BP8 was the most active bee pollen sample, followed by BP5 and BP11, with $\mathrm{IC}_{50}$ values of 2.9 and $3.3 \mathrm{mg} \mathrm{mL}^{-1}$, respectively. For the MCF-7 cell line, the $\mathrm{IC}_{50}$ value of 18 Korean bee pollen samples ranged from 0.9 to $12.7 \mathrm{mg}$ $\mathrm{mL}^{-1}$. Among them, the BP7 sample showed the highest activity, followed by $\mathrm{BP} 2, \mathrm{BP} 1$, and $\mathrm{BP} 11$, with $\mathrm{IC}_{50}$ values of $1.4,1.5$, and $1.9 \mathrm{mg} \mathrm{mL}^{-1}$, respectively. The BP3 sample showed the lowest activity toward MCF-7 compared with the other samples, with an $\mathrm{IC}_{50}$ value of $12.7 \mathrm{mg} \mathrm{mL}^{-1}$. Toward the A549 cell line, 16 Korean EBP samples presented antiproliferative effects, with $\mathrm{IC}_{50}$ values ranging from 5.0 to $20.6 \mathrm{mg} \mathrm{mL}^{-1}$. BP7, BP5, BP6, and BP9 were the most active bee pollen samples, with $\mathrm{IC}_{50}$ values between 5.0 and $9.1 \mathrm{mg} \mathrm{mL}^{-1}$. However, samples from BP3 and BP15 did not show significant antiproliferative effects. For the NCI-H727 cell line, the $\mathrm{IC}_{50}$ value of 18 the Korean samples was between 2.7 and $17.7 \mathrm{mg} \mathrm{mL}^{-1}$. The BP2 sample was the most active $\left(\mathrm{IC}_{50}=2.7 \mathrm{mg} \mathrm{mL}^{-\mathbf{1}}\right)$, followed by BP5, BP9 and BP6, with $\mathrm{IC}_{50}$ values of $3.2,3.4$, and $3.9 \mathrm{mg} \mathrm{mL}^{-1}$, respectively. Toward the AGS cell line, the $\mathrm{IC}_{50}$ value of the 18
Korean bee pollen samples ranged from 2.4 to $8.7 \mathrm{mg}$ $\mathrm{mL}^{-1}$; among them, BP11 was the most active, followed by $\mathrm{BP} 7$, with $\mathrm{IC}_{50}$ values of 2.4 and $2.5 \mathrm{mg} \mathrm{mL}^{-1}$, respectively. Chinese samples showed anticancer effects toward PC-3, MCF-7, A549, NCI-H727, and AGS cancer cell lines with $\mathrm{IC}_{50}$ values of $3.3,2.8,16.1,2.8$, and 1.8 $\mathrm{mg} \mathrm{mL} \mathrm{m}^{-1}$, respectively. However, the antiproliferative effects of bee pollen samples toward five cancer cell lines were less potent than the anticancer agent cisplatin. The abovementioned results showed that EBP7 showed comparatively good activity toward five cancer lines, particularly PC-3, MCF-7, A549, and AGS. The EBP5 sample possessed better inhibitory activity toward four cancer lines, namely, PC-3, A549, NCI-H727 and AGS. However, BP3, a monofloral sample of Actinidia arguta pollen, was observed to show comparatively weak activity toward five cancer lines. BP4, BP12 and BP13 showed relatively weak inhibitory activity. Taken together, pollen grains with heterofloral botanical origin presented preferable inhibitory effects on cancer cell growth compared to those of pollen grains with bifloral and monofloral sources in the current study. However, the EBP sample from China, a monofloral pollen with a 
Nelumbo nucifera origin, presented good effects against PC-3, MCF-7, NCI-H727, and AGS cell lines but not against A549 cells. All the above data demonstrated that the anticancer effects of pollen samples vary with different botanical and geographical origins. In addition, the anticancer activity also depends on the cancer cell line. Therefore, EBPs might be used as a potential supplementary anticancer treatment agent, and specific pollen products can be suggest for different types of cancer.

\section{Discussion}

Bee pollen consists of phenolic and flavonoid compounds that are related to serious therapeutic activities, including antioxidant, antibiotic, antidiarrhoeic and antineoplasic properties [34]. The total phenolic and flavonoid contents in BP have been determined in many previous studies. The total phenolic (TP) and total flavonoid content (TF) was reported in bee pollen from Brazil (TP, 41.5-213.2 $\mathrm{mg} \mathrm{g}^{-1}$ ) [20], from the southern region of Brazil (TP, 19.28-48.90 $\mathrm{mg} \mathrm{g}^{-1}$; $\mathrm{TF}, 2.10-28.33 \mathrm{mg} \mathrm{g}^{-1}$ ) [35], from Northwest Algeria (TP, $30.46 \mathrm{mg} \mathrm{g}^{-1}$; TF, $8.92 \mathrm{mg} \mathrm{g}^{-1}$ ) [36], from the Baltic region (TP, 24.1-45.5 $\mathrm{mg} \mathrm{g}^{-1}$; TF, $6.1-11.6 \mathrm{mg}$ $\mathrm{g}^{-1}$ ) [37], from Portugal (TP, 10.5-16.8 $\mathrm{mg} \mathrm{g}^{-1}$ ) [38], from Venezuela (TP, 3.96-12.867 $\mathrm{mg} \mathrm{g}^{-1}$ ) [39], and from Greece (TP, $10.49 \mathrm{mg} \mathrm{g}^{-1}$ ) [10]. In the present study, the flavonoid and phenolic compound contents of 18 EBP samples from South Korea ranged from 1.84 to $6.66 \mathrm{mg} \mathrm{g}^{-1}$ and from 6.33 to $37.55 \mathrm{mg} \mathrm{g}^{-1}$, respectively. However, the total phenolic and flavonoid compound contents of bee pollen stated in previous studies varied from 3.96 to $213.2 \mathrm{mg} \mathrm{g}^{-1}$ and from 2.1 to $28.33 \mathrm{mg} \mathrm{g}^{-1}$, respectively. Most of the EBP samples contained a higher amount of flavonoid than the amounts in the Chinese bee pollen sample analyzed in this study, and all of the Korean bee pollen samples showed phenolic compound contents that were 17- to 101-fold higher than those of the Chinese sample assessed in the current study. The phenolic compound and flavonoid composition in bee pollen has been well documented by Bridi et al. [18], who reported that three phenolic acids (syringic acid, coumaric acid, and cinnamic acid) and one flavonoid (myricetin) were detected in all 23 pollen samples. In addition, ferulic acid, cinnamic acid, quercetin, apigenin, and rhamnetin were also observed in most samples in considerable amounts. The chemical characterization of the phenolic compounds and flavonoids in our samples need to be further studied.

According to our results, we first demonstrated that pollen grains collect in South Korea that were predominantly from the plant species Robinia pseudoacacia possessed higher phenolic compound and flavonoid contents than those of pollen grains predominantly from Actinidia arguta and Amygdalus persica. However, pollen from the plant species Nelumbo nucifera rarely contained phenolic compounds. Therefore, phenolic compounds and flavonoids in bee pollen vary with botanical and geographical origins, which was consistent with a previous study [17].

DPPH radicals have been widely used to determine the free radical scavenging capacity of various samples. $\mathrm{EC}_{50}$, which is the amount of an antioxidant needed to inhibit $50 \%$ of the initial DPPH concentration, was used to measure the radical scavenging ability. Relatively low $\mathrm{EC}_{50}$ values indicated high radical scavenging activity of the EBP samples. For the DPPH radical scavenging capacity, the $\mathrm{EC}_{50}$ values have been reported to range from 40 to over $500 \mu \mathrm{g} \mathrm{mL}^{-1}$ in pollen samples collected from New Zealand and Portugal [40], from 810 to $4690 \mu \mathrm{g} \mathrm{mL}^{-1}$ in pollen samples from the southern region of Brazil [35], and from 2.16 to $5.87 \mathrm{mg} \mathrm{mL}^{-1}$ in pollen samples from Portugal [38]. In the current study, the $\mathrm{EC}_{50}$ values of the 18 different $\mathrm{EBP}$ samples from Korea varied from 292.0 to over $1000 \mu \mathrm{g}$ $\mathrm{mL}^{-1}$, and the $\mathrm{EC}_{50}$ values of bee pollen stated above are between 40 and $5870 \mu \mathrm{g} \mathrm{mL}^{-1}$. Aside from samples BP3 and BP11, most of the Korean bee pollen presented better DPPH radical scavenging capacity than that of the Chinese sample assessed in this study. The current study indicated that Korean bee pollen samples from Amygdalus persica, Robinia pseudoacacia, and Quercus palustris presented better antioxidant activity than that of pollen from Actinidia arguta and Nelumbo nucifera. Therefore, based on our study, the appropriate origin of collected bee pollen should be chosen to maximize its antioxidant function.

Amyloid plaque is the accumulation of $A \beta$, which is one of the major neuropathological hallmarks of Alzheimer's disease (AD). BACE1 is the major $\beta$-secretase acting in the brain during the abnormal APP amyloidogenic processing pathway. The cholinergic deficit in the cerebral cortex and basal forebrain results in the cognitive impairment of patients with $\mathrm{AD}$, and $\mathrm{AChE}$ hydrolyzes acetylcholine into choline and acetate, which then reduces acetylcholine [41]. BACE1 inhibitors that reduce the formation of $A \beta$ and $A C h E$ inhibitors that increase cholinergic transmission have become two major targets in $\mathrm{AD}$ treatment $[41,42]$. However, there is no information available concerning bee pollen extract inhibitory activity against human BACE1. In the current study, it was first reported that bee pollen extract possesses human BACE1 inhibitory activity, with $\mathrm{EC}_{50}$ values ranging from 236.0 to $1492 \mu \mathrm{g} \mathrm{mL}^{-1}$. Based on these data, the heterofloral bee pollen sample exhibited better 
anti-BACE1 activity than that of the monofloral pollen samples. In addition, bee pollen with Robinia pseudoacacia as the dominant source possessed a better potential inhibitory capacity against BACE1 than that of bee pollen with Quercus palustris as the predominant origin. Therefore, Robinia pseudoacacia-derived pollen could be used as the most potential candidate for anti-BACE1 activity for $\mathrm{AD}$ prevention or treatment. A previous study reported that bee pollen of different geographical origins in Bahia, Brazil, presented AChE inhibitory activity with $\mathrm{EC}_{50}$ values of $3.93-967.53 \mu \mathrm{g} \mathrm{mL}^{-1}$ [43], but unfortunately, in our study, all bee pollen samples did not present potent inhibitory activity against human $\mathrm{AChE}$ at a concentration of $2 \mathrm{mg} \mathrm{mL}^{-1}$. A previous study reported that flavonoids and phenolic compounds derived from natural products showed potent anti-AChE capacity [44]. Bee pollen extracts contain abundant flavonoids and phenolic compounds. Anti-AChE activities were not observed in our samples; perhaps the constituents in these samples had antagonistic effects against AChE. Further constituent isolation and identification of those with inhibitory activity on $\mathrm{AChE}$ should be further studied. Taken together, the results suggest bee pollen extracts could have merit as potential anti-AD agents.

Some previous studies have indicated the antiproliferative effects of bee pollen extracts on cancer. A previous study reported that the $\mathrm{IC}_{50}$ value of bee pollen from Malaysia on MCF-7 cells was $15 \mathrm{mg} \mathrm{mL}^{-1}$ [33]. The cytotoxic activities of Indonesian bee pollen extracts towards the five different cancer cell lines BT474, ChaGo, HepG2, KATO-III, and SW620 varied not only with the solvent used in the extraction but also the bee species and bee product source. Most of the bee pollen extracts did not show cytotoxic activity at a concentration of $20 \mu \mathrm{g} \mathrm{mL}^{-1}$ [33]. Bee pollen polysaccharides from Rosa rugosa (WRPP) collected from China have been reported to possess dose-dependent antiproliferative activities with concentrations from 0 to $5 \mathrm{mg} \mathrm{mL}^{-1}$, and WRPP showed approximately 70\% cytotoxic activity toward HT-29 and HCT116 cancer cell lines at a concentration of $5 \mathrm{mg} \mathrm{mL}^{-1}{ }^{13}$. The antiproliferative effect of German bee pollen samples showed high efficiency, reaching approximately 60 to $70 \%$ inhibition at a concentration of 1 $\mathrm{mg} \mathrm{mL}^{-1}$ against C26 mouse colon tumor cells [45]. In the present study, the antiproliferative effects of the 18 Korean EBP samples varied according to the source, which was consistent with a previous study [36]. All 18 Korean EBP samples showed potent cytotoxic effects on the human cancer cell lines PC-3, MCF-7, A549, NCI$\mathrm{H} 727$, and AGS, with $\mathrm{IC}_{50}$ values ranging from 2.7 to $14.4 \mathrm{mg} \mathrm{mL}^{-1}, 0.9$ to $12.7 \mathrm{mg} \mathrm{mL}^{-1}, 5.0$ to $>25 \mathrm{mg} \mathrm{mL}^{-}$ , 2.7 to $17.7 \mathrm{mg} \mathrm{mL}^{-1}$, and 2.4 to $8.7 \mathrm{mg} \mathrm{mL}^{-1}$, respectively. The anticancer effects of the bee pollen samples varies with botanical and geographical origins. In addition, the anticancer activity also depended on the cancer cell species. Therefore, EBPs might be useful as potential supplementary anticancer treatments and should be chosen in accordance with the cancer to be treated.

The correlation between biological features and phenolic compound or flavonoid contents has been well studied. Some studies have demonstrated a higher correlation between antioxidant and flavonoid and phenolic compound contents. Mesquite pollen extracts showed antioxidant capacity that was related to the flavonol concentration. Radical scavenging activity correlated with the total content of phenolic compounds, while the correlation coefficient was $0.95[32,37]$. However, in the current study, correlation coefficient $(R)$ analysis showed that no significant relation between the phenolic compound or flavonoid contents and antioxidant activity $\left(R^{2}=0.158\right.$ or 0.00005897 , respectively) was observed, which was consistent with previous studies [38, 46]. In addition, it has been reported that the antioxidant activity varies with the solvent used to extract pollen samples, and there is no clear association with their phenolic compound contents [47]. The correlation between phenolic compound content and antioxidant activity is still controversial for bee pollen.

In addition, there was no observed direct correlation between BACE1 inhibitory activity $\left(R^{2}=0.09420\right.$, or 0.1034 , respectively) or antiproliferative capacity against PC-3 $\left(R^{2}=0.006436\right.$, or 0.0005091 , respectively), MCF-7 $\left(R^{2}=0.05512\right.$ or 0.1239 , respectively $), A 549\left(R^{2}=0.1748\right.$, or 0.1243 , respectively), NCI-H727 $\left(R^{2}=0.01843\right.$, or 0.04156, respectively), and AGS $\left(R^{2}=0.01843\right.$, or 0.00009681 , respectively) and total phenolic compound or flavonoid contents in the EBP samples (Fig. 2). This indicated that there are some other bioactive constituents, such as phytosterols, phospholipids, fatty acids, and organic carotenoid pigments, that may be responsible for the biological properties of bee pollen [48]. The main constituents imparting these biological properties and health-promoting effects should be further isolated and identified.

\section{Conclusion}

The ethanol extracts of bee pollen collected from different locations in South Korea has different DPPH radical scavenging activities and BACE1 in vitro inhibitory activities. In addition, Korean bee pollen ethanol extracts exhibited inhibitory effects on five human cancer cell lines. Fundamentally, Korean bee pollen-derived preparations could be considered nutritional addition to food that could prevent various diseases related to free radicals, neurodegenerative 


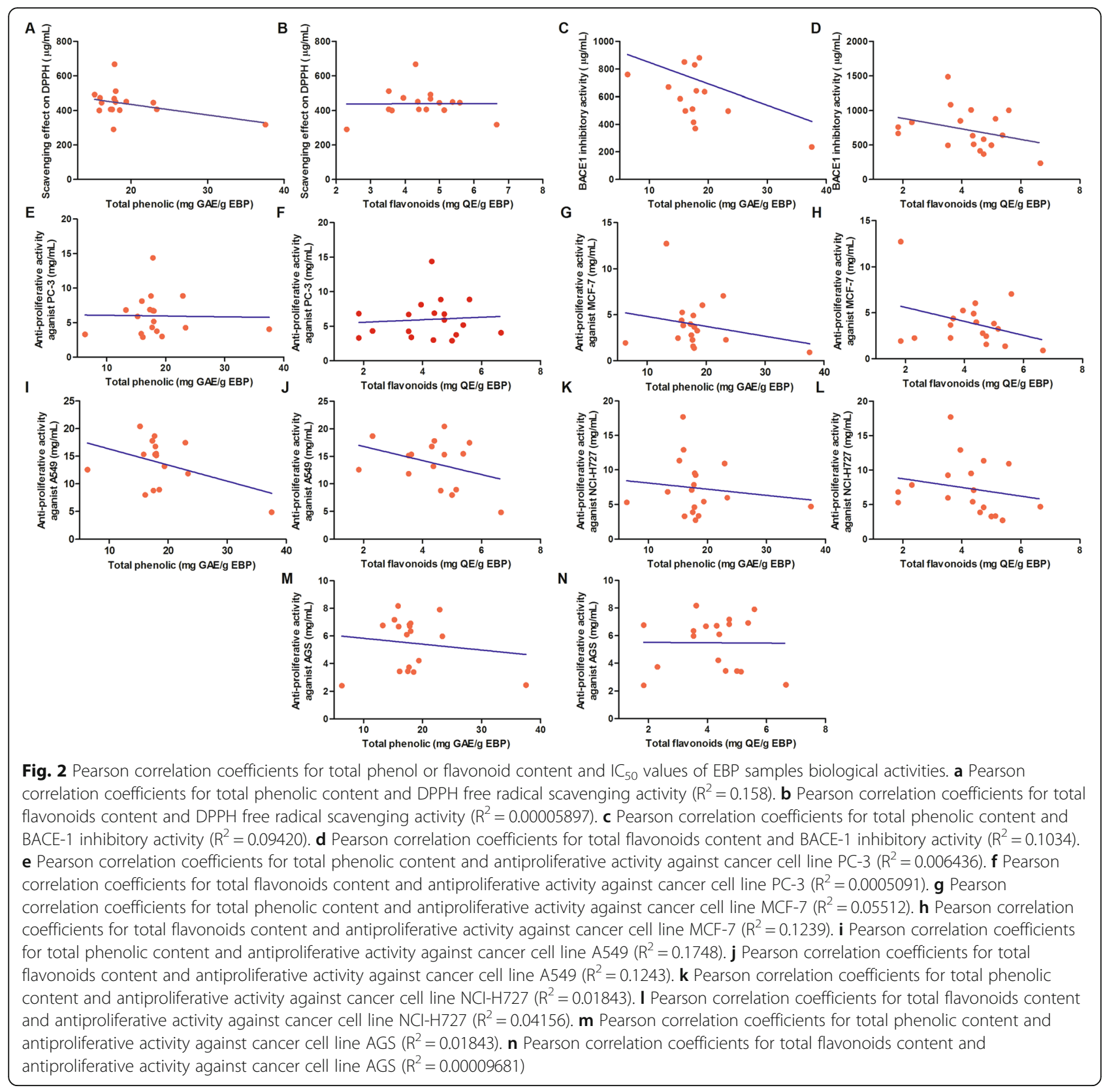

problems and cancer. This study demonstrated the potential anti-BACE1 activity of EBPs based on an in vitro assay system for the first time. However, in the current study, there was no significant relation between the phenolic compound or flavonoid contents and the antioxidant activity and anti-BACE1, and anticancer effects. Because the biological activities of bee pollen depend on the plant source and environmental conditions, such as geographical location, identification and selection, high-quality bee pollen is needed. In conclusion, our findings provide a scientific basis for evaluating the biological activities of bee pollen samples collected from several parts of South
Korea and varied with botanical source. These findings might be used as a reference for consumer choices, bee pollen production, and industrial exploration to maintain human health.

\section{Abbreviations}

BP: Bee pollen; EBP: Ethanol extract of pollen; Anti-BACE1: $\beta$-amyloid precursor cleavage enzyme; AChE: Acetylcholinesterase; DPPH: 2,2-diphenyl1-picrylhydrazyl; DTNB: 5,5-Dithiobis-(2-nitrobenzoic acid);

ATChl: Acetylthiocholine iodide; MTT: 3-(4,5-dimethylthiazol-2-yl)-2,5-diphenyl tetrazolium bromide; FBS: Fluorogenic peptide substrate; ATCC: American type culture collection; BHI: Brain Heart Infusion; MEM: Minimum essential medium; FBS: Fetal bovine serum; QE: Quercetin equivalents; GAE: Gallic acid equivalents; TP: Total phenolic; TF: Total flavonoids content; AD: Alzheimer's disease; APP: Amyloid precursor protein (APP); A $\beta$ : $\beta$-amyloid; WRPP: Pollen polysaccharides from Rosa rugose 


\section{Acknowledgements}

We specifically thank Prof. Young-Joon Ahn of College of Agriculture and Life Sciences, Seoul National University, Seoul, South Korea who designed this study and reviewed the manuscript.

\section{Authors' contributions}

$X W$ and YX contributed to manuscript writing and editing. YJA contributed to design the study and reviewed the manuscript. YCZ and JH contributed to perform the experiments. WH, LZ and YLZ contributed to bee pollen sample collection and extraction. DC, MS and DW contributed to data analysis. All the authors critically reviewed the manuscript and approved the final version.

\section{Funding}

This work was funded by Cooperative Research Program for Agriculture Science \& Technology Development (PJ010487) from the Rural Development Administration (RDA) of the Republic of Korea, Medical and Health Science and Technology Program of Zhejiang Province (2018KY505), Wenzhou Municipal Science and Technology Bureau Project (Y20180612). The founder had no role in study design, experiments operation, data collection and analysis, manuscript preparation or decision to publish.

\section{Availability of data and materials}

The datasets used and/or analyzed in the current study are available from the corresponding author with a reasonable request.

\section{Ethics approval and consent to participate}

Not applicable.

\section{Consent for publication}

Not applicable.

\section{Competing interests}

The authors declare that they have no potential conflicts of interests.

\section{Author details}

${ }^{1}$ The First Affiliated Hospital of Wenzhou Medical University, Wenzhou, Zhejiang 325000, China. ${ }^{2}$ School of Pharmaceutical Sciences, Wenzhou Medical University, Wenzhou, Zhejiang 325035, China. ${ }^{3}$ School of the First Clinical Medical Sciences, Wenzhou Medical University, Wenzhou, Zhejiang 325035, China. ${ }^{4}$ College of Agriculture and Life Sciences, Seoul National University, Seoul 151-921, South Korea.

\section{Received: 11 October 2019 Accepted: 9 July 2020}

\section{Published online: 25 July 2020}

\section{References}

1. Feás X, Vázquez-Tato MP, Estevinho L, Seijas JA, Iglesias A. Organic bee pollen: botanical origin, nutritional value, bioactive compounds, antioxidant activity and microbiological quality. Molecules. 2012;17:8359-77.

2. Kostić AŽ, Kaluđerović LM, Dojčinović BP, Barać MB, Babić VB, MačukanovićJocić MP. Preliminary investigation of mineral content of pollen collected from different Serbian maize hybrids - is there any potential nutritional value? J Sci Food Agric. 2017;97:2803-9.

3. Bahadur S, Ahmad M, Mir S, Zafar M, Sultana S, Ashfaq S, Arfan M. Identification of monocot flora using pollen features through scanning electron microscopy. Microsc Res Tech. 2018;81:599-613.

4. Almeida-Muradiana LB, Pamplonaa LC, Coimbraa S, Barth OM. Chemical composition and botanical evaluation of dried bee pollen pellets. J Food Compos Anal. 2005;18:105-11.

5. Campos MGR, Bogdanov S, Almeida-Muradian LB, Szczesna T, Mancebo $Y$, Frigerio C, Ferreira F. Pollen composition and standardization of analytical methods. J Apicult Res. 2008:47:154-61.

6. Nogueira C, Iglesias A, Feás X, Estevinho LM. Commercial bee pollen with different geographical origins: a comprehensive approach. Int J Mol Sci. 2012;13:11173-87.

7. Kroyer $\mathrm{G}$, Hegedus $\mathrm{N}$. Evaluation of bioactive properties of pollen extracts as functional dietary food supplement. Innov Food Sci Emerg. 2001;2:171-4.

8. Şahin S, Karkar B. The antioxidant properties of the chestnut bee pollen extract and its preventive action against oxidatively induced damage in DNA bases. J Food Biochem. 2019;43:e12888.
9. Lee KH, Kim AJ, Choi EM. Antioxidant and antiinflammatory activity of pine pollen extract in vitro. Phytother Res. 2009;23:41-8.

10. Graikou K, Kapeta S, Aligiannis N, Sotiroudis G, Chondrogianni N, Gonos E, Chinou I. Chemical analysis of Greek pollen-antioxidant, antimicrobial and proteasome activation properties. Chem Cent J. 2011;5:33.

11. Nikolaieva N, Kačániová M, González JC, Grygorieva O, Nôžková J. Determination of microbiological contamination, antibacterial and antioxidant activities of natural plant hazelnut (L.) pollen. J Environ Sci Health B. 2019;54:525-32.

12. Bakour M, Al-Waili NS, El Menyiy N, Imtara H, Figuira AC, Al-Waili T, Lyoussi B. Antioxidant activity and protective effect of bee bread (honey and pollen) in aluminum-induced anemia, elevation of inflammatory makers and hepato-renal toxicity. J Food Sci Technol. 2017;54:4205-12.

13. Wang B, Diao Q, Zhang Z, Liu Y, Gao Q, Zhou Y, Li S. Antitumor activity of bee pollen polysaccharides from Rosa rugosa. Mol Med Rep. 2013;7:1555-8.

14. Sobral F, Calhelha RC, Barros L, Dueñas M, Tomás A, Santos-Buelga C, VilasBoas M, Ferreira IC. Flavonoid Composition and Antitumor Activity of Bee Bread Collected in Northeast Portugal. Molecules. 2017;22:248.

15. Attia YA, Al-Hanoun A, El-Din AE, Bovera F, Shewika YE. Effect of bee pollen levels on productive, reproductive and blood traits of NZW rabbits. J Anim Physiol Anim Nutr. 2011;95:294-303.

16. Denisow B, Denisow-Pietrzyk M. Biological and therapeutic properties of bee pollen: a review. J Sci Food Agric. 2016;96:4303-9.

17. Carpes ST, de Alencar SM, ISR C, TLC O, Mourão GB, CWI H, et al. Polyphenols and palynological origin of bee pollen of Apis mellifera L. from Brazil. Characterization of polyphenols of bee pollen. J Food. 2013;11:150-61.

18. Bridi R, Atala E, Pizarro PN, Montenegro G. Honeybee pollen load: phenolic composition and antimicrobial activity and antioxidant capacity. J Nat Prod. 2019;82:559-65.

19. Szczęsna T. Study of the sugar composition of honeybee-collected pollen. J Apicult Res. 2007;5:15-22.

20. Freire KRL, Lins ACS, Dórea MC, Santos FAR, Camara CA, Silva TMS. Palynological origin, phenolic content, and antioxidant properties of honeybee-collected pollen from Bahia, Brazil. Molecules. 2012;17:1652-64.

21. Barth OM, Freitas AS, Oliveira ES, Silva RA, Maester FM, Andrella RR, et al. Evaluation of the botanical origin of commercial dry bee pollen load batches using pollen analysis: a proposal for technical standardization. An Acad Bras Cienc. 2010;82:893-902.

22. Wang $X$, Sankarapandian K, Cheng Y, Woo SO, Kwon HW, Perumalsamy H, Ahn YJ. Relationship between total phenolic contents and biological properties of propolis from 20 different regions in South Korea. BMC Complement Altern Med. 2016;16:65.

23. Ding X, Hou YL, Hou WR. Structure elucidation and antioxidant activity of a novel polysaccharide isolated from boletus speciosus Forst. Int J Biol Macromol. 2012;50:613-8.

24. Suh YH, Checler F. Amyloid precursor protein, presenilins, and a-synuclein: molecular pathogenesis and pharmacological applications in Alzheimer's disease. Pharmacol Rev. 2002;54:469-525.

25. Wang X, Kim JR, Lee SB, Kim YJ, Jung MY, Kwon HW, et al. Effects of curcuminoids identified in rhizomes of Curcuma longa on BACE-1 inhibitory and behavioral activity and lifespan of Alzheimer's disease Drosophila models. BMC Complement Altern Med. 2014;14:88.

26. Moss DE, Perez RG, Kobayashi H. Cholinesterase inhibitor therapy in Alzheimer's: the limits and tolerability of irreversible CNS-selective acetylcholinesterase inhibition in primates. J Alzheimers Dis. 2017;55:1285-94.

27. Colović MB, Krstić DZ, Lazarević-Pašti TD, Bondzic AM, Vasic VM. Acetylcholinesterase inhibitors: pharmacology and toxicology. Curr Neuropharmacol. 2013;11:315-35.

28. Gerritsen J, Smidt H, Rijkers GT, de Vos WM. Intestinal microbiota in human health and disease: the impact of probiotics. Genes Nutr. 2011;6:209-40.

29. Bell V, Ferrão J, Pimentel L, Pintado M, Fernandes T. One Health, Fermented Foods, and Gut Microbiota. Foods. 2018;7:195.

30. Sarker SD, Nahar L, Kumarasamy Y. Microtitre plate-based antimicrobial assay incorporating resazurin as an indicator of cell growth, and its application in the in vitro antibacterial screening of phytochemicals. Methods. 2007:42:321-4.

31. Morgan DML. Tetrazolium (MTT) assay for cellular viability and activity. Methods Mol Biol. 1998;79:179-83.

32. Miguel MG, Doughmi O, Aazza S, Antunes D, Lyoussi B. Antioxidant, antiinflammatory and acetylcholinesterase inhibitory activities of propolis from different regions of Morocco. Food Sci Biotechnol. 2014;23:313-22. 
33. Kustiawan PM, Puthong S, Arung ET, Chanchao C. In vitro cytotoxicity of Indonesian stingless bee products against human cancer cell lines. Asian Pac J Trop Biomed. 2014;4:549-56.

34. Campos MG, Mitchel K, Cunha A, Markham K. A systemic approach to the characterization of bee pollens via their flavonoid/phenolic profiles. Phytochem Anal. 1997:8:181-5.

35. Carpes ST, Mourão GB, SMde A, Masson ML. Chemical composition and free radical scavenging activity of Apis mellifera bee pollen from southern Brazil. Braz J Food Technol. 2009;12:220-9.

36. Rebiai A, Lanez T. Chemical composition and antioxidant activity of Apis mellifera bee pollen from Northwest Algeria. J Fundam Appl Sci. 2012;4:155-63.

37. Kaškonienè V, Ruočkuviene $G$, Kaškonas P, Akuneca L, Maruška A. Chemometric Analysis of Bee Pollen Based on Volatile and Phenolic Compound Compositions and Antioxidant Properties. Food Anal Methods. 2105:8:1150-63.

38. Morais M, Moreiraa L, Feásb X, Estevinho LM. Honeybee-collected pollen from five Portuguese natural parks: Palynological origin, phenolic content, antioxidant properties and antimicrobial activity. Food Chem Toxicol. 2011; 49:1096-101.

39. Pérez-Pérez EM, Vit P, Rivas E, Sciortino R, Sosa A, Tejada D, et al. Antioxidant activity of four color fractions of bee pollen from Mérida, Venezuela. Arch Latinoam Nutr. 2012;62:375-80.

40. Campos MG, Webby RF, Markham KR, Mitchell KA, Da Cunha AP. Age-induced diminution of free radical scavenging capacity in bee pollens and the contribution of constituent flavonoids. J Agric Food Chem. 2003:51:742-5.

41. Vauzour D. Effect of flavonoids on learning, memory and neurocognitive performance: relevance and potential implications for Alzheimer's disease pathophysiology. J Sci Food Agric. 2014;94:1042-56.

42. Vassar R. BACE1 inhibitor drugs in clinical trials for Alzheimer's disease. Alzheimers Res Ther. 2014;6:89.

43. Araújo JS, Chambó ED, Costa MAPC, da Silva SMP C, Lopes de Carvalho CA, Estevinho LM. Chemical Composition and Biological Activities of Mono- and Heterofloral Bee Pollen of Different Geographical Origins. Int J Mol Sci. 2017; 18:921.

44. Nwidu LL, Elmorsy E, Thornton J, Wijamunige B, Wijesekara A, Tarbox R, et al. Anti-acetylcholinesterase activity and antioxidant properties of extracts and fractions of Carpolobia lutea. Pharm Biol. 2017:55:1875-83.

45. Mărgăoan $R$, Zăhan M, Mărghitaş LA, Dezmirean DS, Erler S, Bobiş O Antiproliferative activity and apoptotic effects of Filipendula ulmaria pollen against C26 mice colon tumor cells. J Apic Sci. 2016;60:135-44.

46. Mărghitaş LA, Stanciua OG, Dezmireana DS, Bobişa O, Popescua O, Bogdanovb S, et al. In vitro antioxidant capacity of honeybee-collected pollen of selected floral origin harvested from Romania. Food Chem. 2009; 115:878-83.

47. Silva TMS, Câmara CA, Lins AC, Barbosa-Filho JM, Silva EMS, Freitas BM, et al. Chemical composition and free radical scavenging activity of pollen loads from stingless bee Melipona subnitida Ducke. J Food Compos Anal. 2006;19: 507-11

48. Karampour NS, Hemmati AA, Malmir A. The anxiolytic effect of bee pollen hydroalcoholic extract in mice. Natl J Physiol Pharm Pharmacol. 2107;7:301-5.

\section{Publisher's Note}

Springer Nature remains neutral with regard to jurisdictional claims in published maps and institutional affiliations.

Ready to submit your research? Choose BMC and benefit from:
- fast, convenient online submission
- thorough peer review by experienced researchers in your field
- rapid publication on acceptance
- support for research data, including large and complex data types
- gold Open Access which fosters wider collaboration and increased citations
- maximum visibility for your research: over 100M website views per year
At BMC, research is always in progress.
Learn more biomedcentral.com/submissions

